Prepared in cooperation with the U.S. Environmental Protection Agency

\title{
Geophysical, Stratigraphic, and Flow-Zone Logs of Selected Wells in Cayuga County, New York, 2001-2011
}

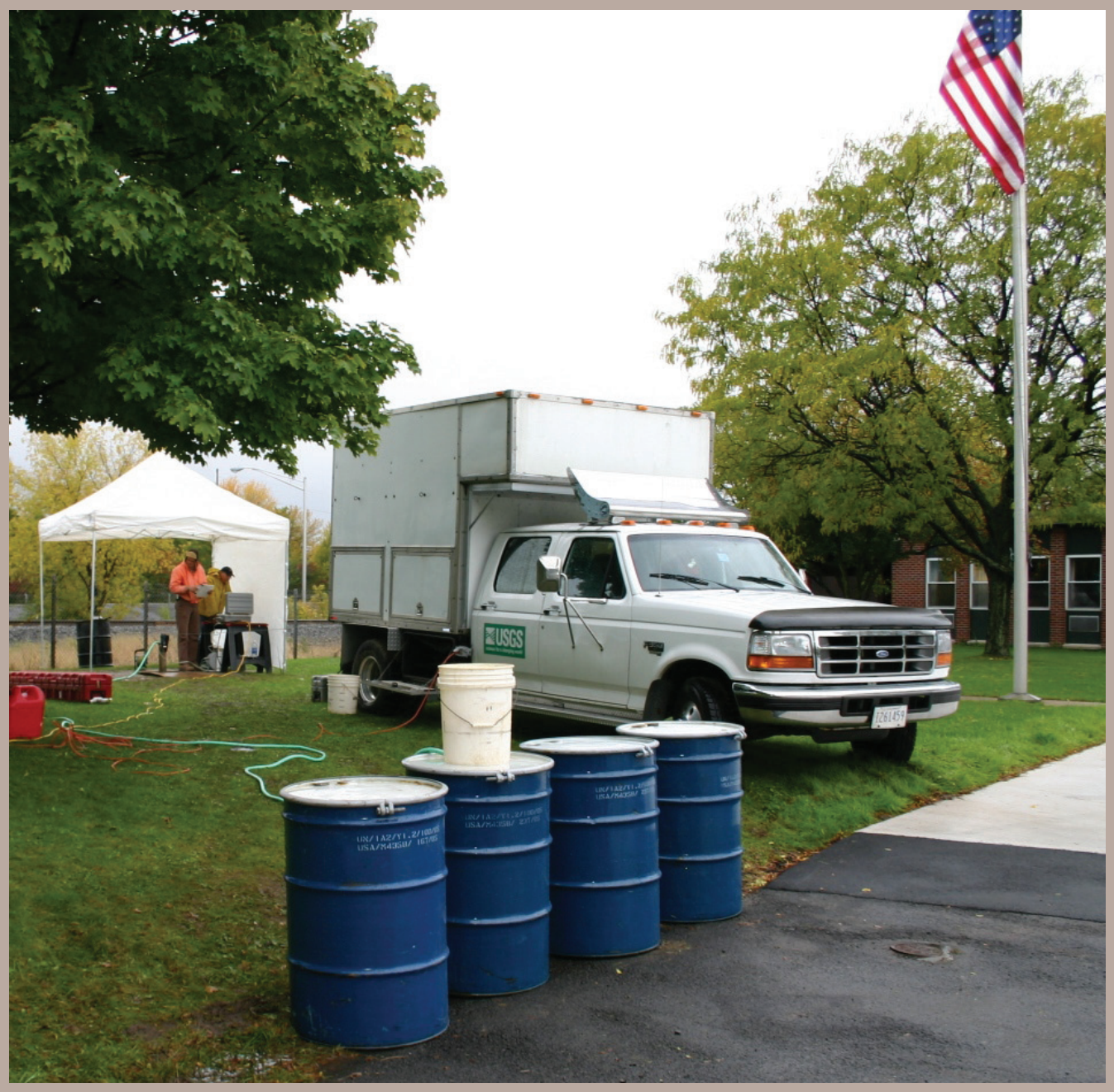

Open-File Report 2011-1319

U.S. Department of the Interior U.S. Geological Survey 
Cover. Geophysical logging at monitor well CY-229 (EPA-20) near Clark Street in Auburn, New York, in 2005. 


\section{Geophysical, Stratigraphic, and Flow-Zone Logs of Selected Wells in Cayuga County, New York, 2001-2011}

By David A.V. Eckhardt, John H. Williams, and J. Alton Anderson

Prepared in cooperation with the U.S. Environmental Protection Agency

Open-File Report 2011-1319 


\title{
U.S. Department of the Interior \\ KEN SALAZAR, Secretary \\ U.S. Geological Survey \\ Marcia K. McNutt, Director
}

\author{
U.S. Geological Survey, Reston, Virginia: 2012
}

For more information on the USGS - the Federal source for science about the Earth, its natural and living resources, natural hazards, and the environment—visit http://www.usgs.gov or call 1-888-ASK-USGS.

For an overview of USGS information products, including maps, imagery, and publications, visit http://www.usgs.gov/pubprod

To order this and other USGS information products, visit http://store.usgs.gov

Any use of trade, product, or firm names is for descriptive purposes only and does not imply endorsement by the U.S. Government.

Although this report is in the public domain, permission must be secured from the individual copyright owners to reproduce any copyrighted materials contained within this report.

Suggested citation:

Eckhardt, D.A., Williams, J.H., and Anderson, J.A., 2012, Geophysical, stratigraphic, and flow-zone logs of selected wells in Cayuga County, New York, 2001-2011: U.S. Geological Survey Open-File Report 2011-1319, 13 p., available at http://pubs.usgs.gov/of/2011/1319. 


\section{Acknowledgments}

The authors thank the following individuals for their cooperation and assistance: Isabel Rodrigues, Robert Alvey, Donald Bussey, Jack Harmon, Alan Humphrey, and John DiMartino of the U.S. Environmental Protection Agency; Charles Ver Straeten of the New York State Geological Survey; Kevin Kelly of the New York State Department of Environmental Conservation; Eileen O'Connor, Mary Jump, Nick Colas, and Bruce Natale of Cayuga County; Edward Trufant and Robert Kneaskern of the Village of Union Springs; Paul Hare of the General Electric Company; Ralph Morse of O'Brien and Gere Engineers, Inc.; and the residents who graciously allowed access to their wells. 


\section{Contents}

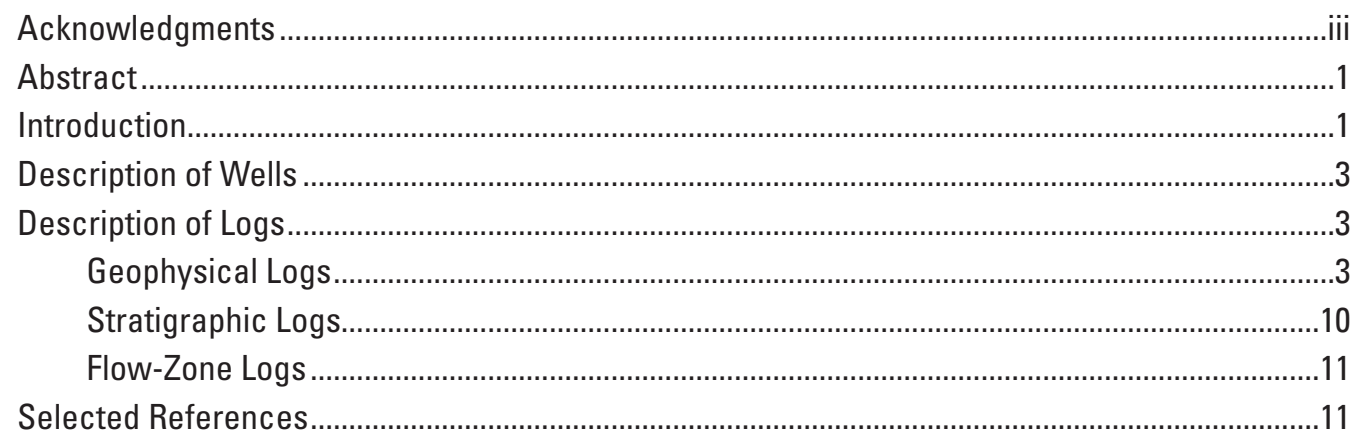

\section{Figures}

1. Map showing location of study area and selected wells and outcrops in Cayuga County, New York

\section{Tables}

1. Information for surveyed wells with borehole logs in Cayuga County, New York,

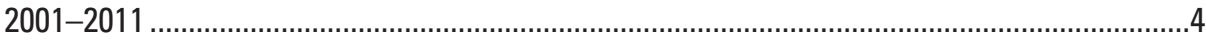

2. Borehole information collected for wells surveyed in Cayuga County, New York, 2001-2011 


\section{Conversion Factors and Datum}

Inch/Pound to SI

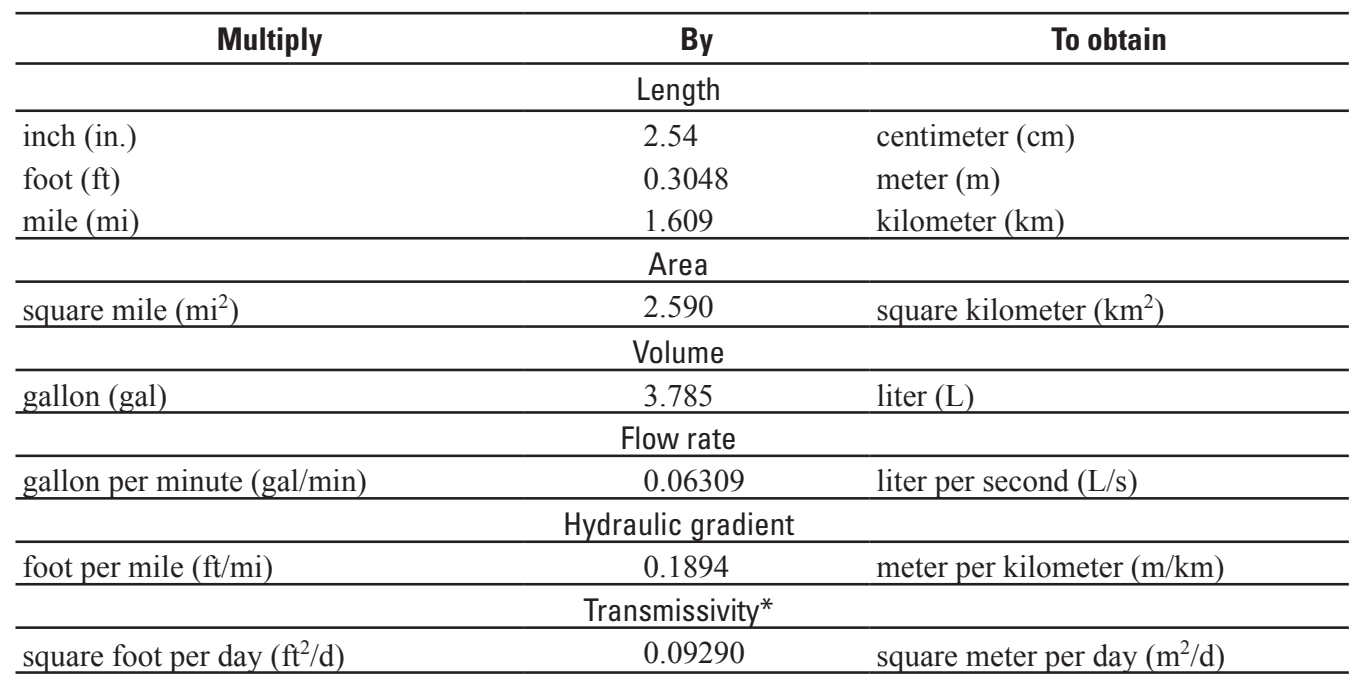

Temperature in degrees Celsius $\left({ }^{\circ} \mathrm{C}\right)$ may be converted to degrees Fahrenheit $\left({ }^{\circ} \mathrm{F}\right)$ as follows:

$$
{ }^{\circ} \mathrm{F}=\left(1.8 x^{\circ} \mathrm{C}\right)+32
$$

Vertical coordinate information (above mean sea level) is referenced to either "North American Vertical Datum of 1988 (NAVD 88)" or "National Geodetic Vertical Datum of 1929 (NGVD 29)."

Horizontal coordinate information is referenced to "North American Datum of 1983 (NAD83)"

Altitude, as used in this report, refers to distance above the vertical datum.

*Transmissivity: The standard unit for transmissivity is cubic foot per day per square foot times foot of aquifer thickness $\left[\left(\mathrm{ft}^{3} / \mathrm{d}\right) / \mathrm{ft}^{2}\right] \mathrm{ft}$. In this report, the mathematically reduced form, foot squared per day $\left(\mathrm{ft}^{2} / \mathrm{d}\right)$, is used for convenience. 


\section{Acronyms}

$\begin{array}{ll}\text { ATV } & \text { acoustic televiewer } \\ \text { CY } & \text { Cayuga County (prefix to well identifier) } \\ \text { Deg } & \text { degree (temperature) } \\ \text { GE } & \text { General Electric Company } \\ \text { MN } & \text { magnetic north } \\ \text { NYSDEC } & \text { New York State Department of Environmental Conservation } \\ \text { NYSEG } & \text { New York State Electric and Gas utility company } \\ \text { OTV } & \text { optical televiewer } \\ \text { PDF } & \text { portable document format } \\ \text { PVC } & \text { polyvinyl-chloride } \\ \text { REAC } & \text { Response Engineering and Analytical Contractor } \\ \text { USEPA } & \text { U.S. Environmental Protection Agency } \\ \text { USGS } & \text { U.S. Geological Survey } \\ \text { VOCs } & \text { volatile-organic compounds }\end{array}$




\title{
Geophysical, Stratigraphic, and Flow-Zone Logs of Selected Wells in Cayuga County, New York, 2001-2011
}

\author{
By David A.V. Eckhardt, John H. Williams, and J. Alton Anderson
}

\begin{abstract}
Geophysical logs were collected and analyzed along with bedrock core samples and bedrock outcrops to define the bedrock stratigraphy and flow zones penetrated by 93 monitor and water-supply wells in Cayuga County, New York. The work was completed from 2001 through 2011 as part of an investigation of volatile-organic compound contamination in the carbonate-bedrock aquifer system between Auburn and Union Springs. The borehole logs included gamma, caliper, wellbore image, fluid property, and flow logs. The log information was used with bedrock core samples to define the regional stratigraphy, evaluate flow zones within the bedrock aquifers, and develop and implement a multilevel monitoring design for groundwater levels and water quality within the study area.
\end{abstract}

\section{Introduction}

Volatile-organic compounds (VOCs) have been detected in water sampled from more than 50 water-supply wells between the city of Auburn and the village of Union Springs in central Cayuga County, New York (fig. 1). More than 300 wells were sampled in the area by the Cayuga County Environmental Health Department, the New York State Department of Environmental Conservation (NYSDEC), the New York State Department of Health, and the U.S. Environmental Protection Agency (USEPA) following the detection of VOCs in the Union Springs municipal wells in 2000. The area was declared a Superfund Site and listed on the National Priorities List in 2002 (U.S. Environmental Protection Agency, 2002).

Geophysical logs record measurements of physical properties of the bedrock penetrated by wells. The geophysical probes are lowered into a well to collect continuous and point data that are graphically displayed on a depth scale. Multiple logs and descriptions of rock core samples, when available, are typically integrated as a suite of logs that can provide a composite analysis of the borehole. The log information is used in hydrogeologic and environmental investigations to evaluate well construction, rock lithology, stratigraphy, fracture patterns, permeability and porosity, and water quality. The information is also useful for placement of monitoring zones in wells and for characterizing the hydrogeology of contamination sites.

From 2001 through 2011, the U.S. Geological Survey (USGS) collected and compiled geophysical logs from selected monitor and water-supply wells as part of the investigation of VOC contamination in the carbonate-bedrock aquifer in Cayuga County. The USGS analyzed the geophysical logs along with core samples and inspected outcrops of the bedrock to define the stratigraphic units penetrated by wells, evaluate flow zones within the bedrock aquifers, and develop and install a multilevel monitoring system for the study area. Thirty-seven borehole logs available prior to 2003 were presented in Anderson and others (2004). This report revises and updates the information in Anderson and others (2004) and includes information on geophysical logs that have been conducted at an additional 56 wells from 2003 through 2011. This report describes the methods used in the study and presents the updated geophysical, stratigraphic, and flow-zone logs for the 93 wells logged within the study area.

The study area occupies 7 square miles $\left(\mathrm{mi}^{2}\right)$ between the City of Auburn and the Village of Union Springs in central Cayuga County (fig. 1). The area is underlain by glacial till of varying thickness and carbonate, clastic, and evaporite bedrock units of Silurian and Devonian age that regionally dip southward at about 50 feet per mile (ft/mi) (Kantrowitz, 1970). The area is part of the Finger Lakes region and lies between Owasco Lake to the east and Cayuga Lake to the west (fig. 1). The local topography consists of gently rolling hills of the glaciated Appalachian Plateau and has altitudes that range from about 800 feet (ft) above sea level in the south-central part of the study area to about $485 \mathrm{ft}$ above sea level at Cayuga Lake. 


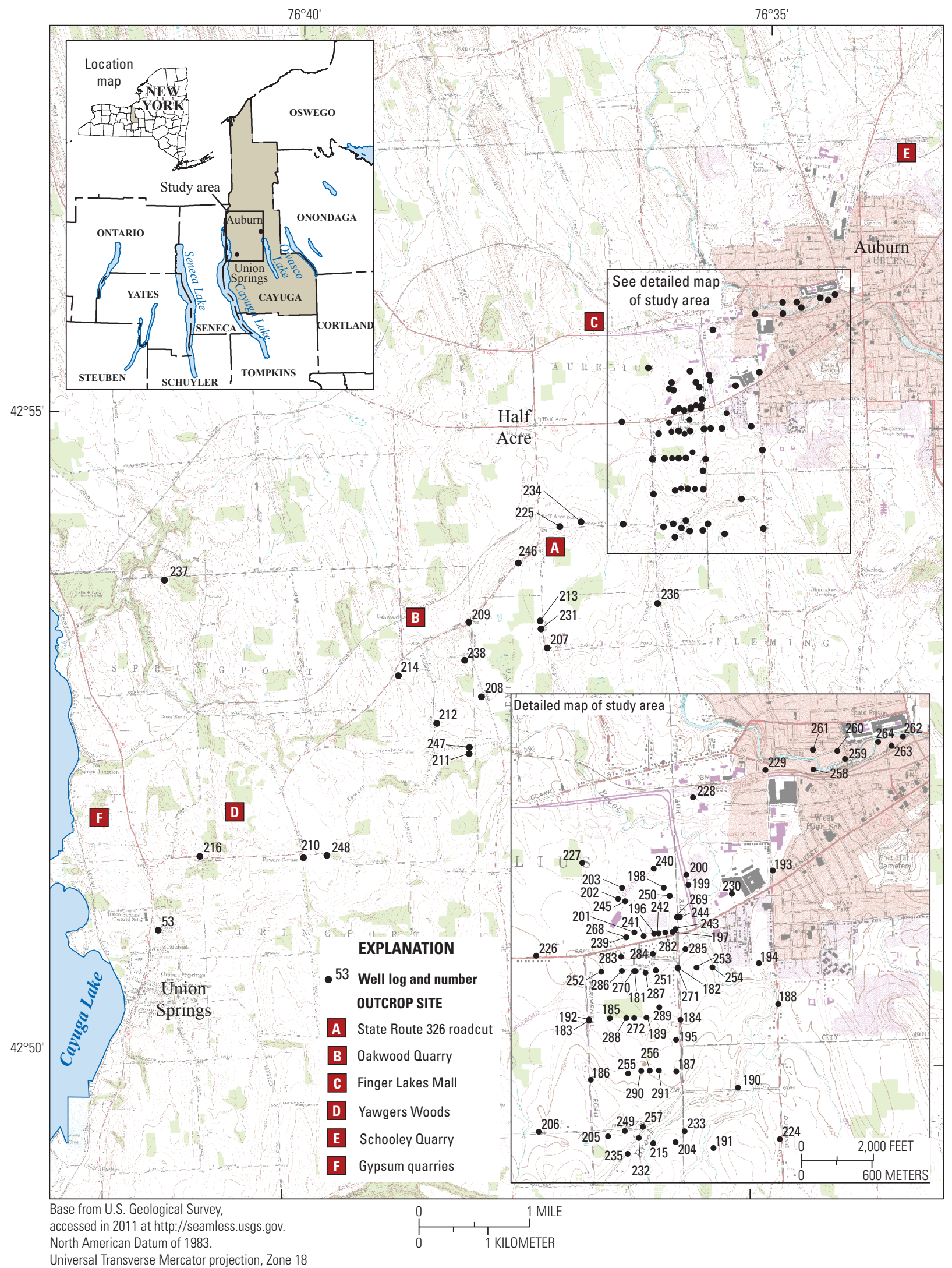

Figure 1. Location of study area and selected wells and outcrops in Cayuga County, New York. 


\section{Description of Wells}

Geophysical logs were collected from 93 wells-26 USEPA and NYSDEC monitor wells, 38 private monitor wells, 20 private residential wells, 7 monitor wells owned by a utility company, and 2 municipal wells. Core samples were examined from 41 wells, and the lithologic, stratigraphic, structural, and faunal descriptions are available from three of the cored wells (CY-181, CY-186, and CY-196) to supplement the geophysical logs. The well locations are shown in figure 1, and well information and logging dates are given in table 1. The types and sources of logs and core samples collected from the wells are given in table 2. The logs are available online for display and download in log Ascii standard (LAS), portable document format (PDF), and WellCad (WCL) formats. Below is a link to the Web site for online access:

\section{http://ny.water.usgs.gov/projects/geologs.}

Most monitor wells (table 1) were constructed as test wells with open 4-inch (in.)-diameter boreholes below steel casing that is sealed with grout into the bedrock. After logging was completed, the USEPA boreholes were completed with multizone monitoring systems of 1.5-in.-diameter polyvinyl-chloride (PVC) casing and inflated packers that isolate as many as 10 discrete stratigraphic intervals, except CY-191, which remains as an open borehole. Four monitor wells (CY-192-CY-195) were constructed by the NYSDEC as test wells with multiple telescopic steel casings and an open-hole interval near the bottom. The private monitor wells, which are associated with a former industrial facility, were completed after logging the 4-in.-diameter open boreholes with grouted 2-in.-diameter PVC casing and screens with sand-packed discrete intervals near the bottom. Natural gamma logs were collected in seven of the private monitor wells through the completed 2-in.-diameter PVC casing. One private monitor well (CY-196) was not accessible for logging, but its core is described. Twenty wells constructed for domestic water supply were completed as 6-in.-diameter open holes below steel casing set into the top of bedrock. Well CY-216 is used for a municipal town hall and is cased more than $100 \mathrm{ft}$ into bedrock. Well CY-53 provides municipal water supply and is an open borehole below steel casing that terminates near the top of bedrock.

\section{Description of Logs}

The geophysical logs collected from November 2001 through January 2011 include natural gamma, single-point resistance, mechanical-and acoustic-caliper, optical-televiewer (OTV) and acoustic-televiewer (ATV), single-point resistance, fluid-resistivity, temperature, and flow logs (appendix 1). The geophysical logs and rock core descriptions presented in this report were collected from 58 wells by the USGS, 4 wells by a USEPA contractor, and 31 wells by a private contractor.

The geophysical logs summarized in this report are available in LAS, text file (TXT), PDF, and WCL formats from the USGS geophysical log archive at http://ny.water.usgs.gov/projects/geologs/. The WellCad Reader ${ }^{1}$ program, which may be obtained free of charge through $h t t p: / / w w w . a l t . l u / d o w n l o a d s . h t m$, allows the logs to be displayed, tabulated, and printed at user-specified vertical scales. Core samples for selected wells are available for inspection at the USGS office in Ithaca, N.Y. The following sections describe details of the composite geophysical, flow-zone, and stratigraphic logs that are summarized in tables 1 and 2.

\section{Geophysical Logs}

The geophysical logs used in this investigation are described briefly below. The logs include natural gamma, caliper, singlepoint resistance, wellbore image, fluid properties, and flowmeter. Gamma logs were collected by a borehole tool that senses natural gamma radiation from the earth material around the wellbore. The caliper logs were collected by mechanical and acoustical methods. Wellbore-image logs were collected with video cameras and ATVs and OTVs. Fluid-property logs included fluidresistivity and temperature measurements. Flowmeter logs were collected by heat-pulse, electromagnetic, and spinner methods. Additional information on geophysical logs and logging for groundwater investigations is presented in Keys (1990), American Society for Testing and Materials (2010), and Williams and Lane (1998).

Gamma logs measure the gamma radiation of rocks surrounding the wellbore. Major natural gamma emitters are uranium, thorium, and daughter (radioactive decay) products of potassium-40. Rock units with relatively high gamma radiation when compared with other lithologic units include shales, bentonites, and other argillaceous units as well as phosphate-rich zones. The gamma tool has a vertical resolution of 1 to $2 \mathrm{ft}$. Gamma logs collected in open holes and through steel and PVC casing were the primary logs used for lithologic identification and stratigraphic correlation.

${ }^{1}$ Use of the trade name WellCAD Reader in this report is for identification purposes only and does not constitute endorsement by the U.S. Geological Survey. 


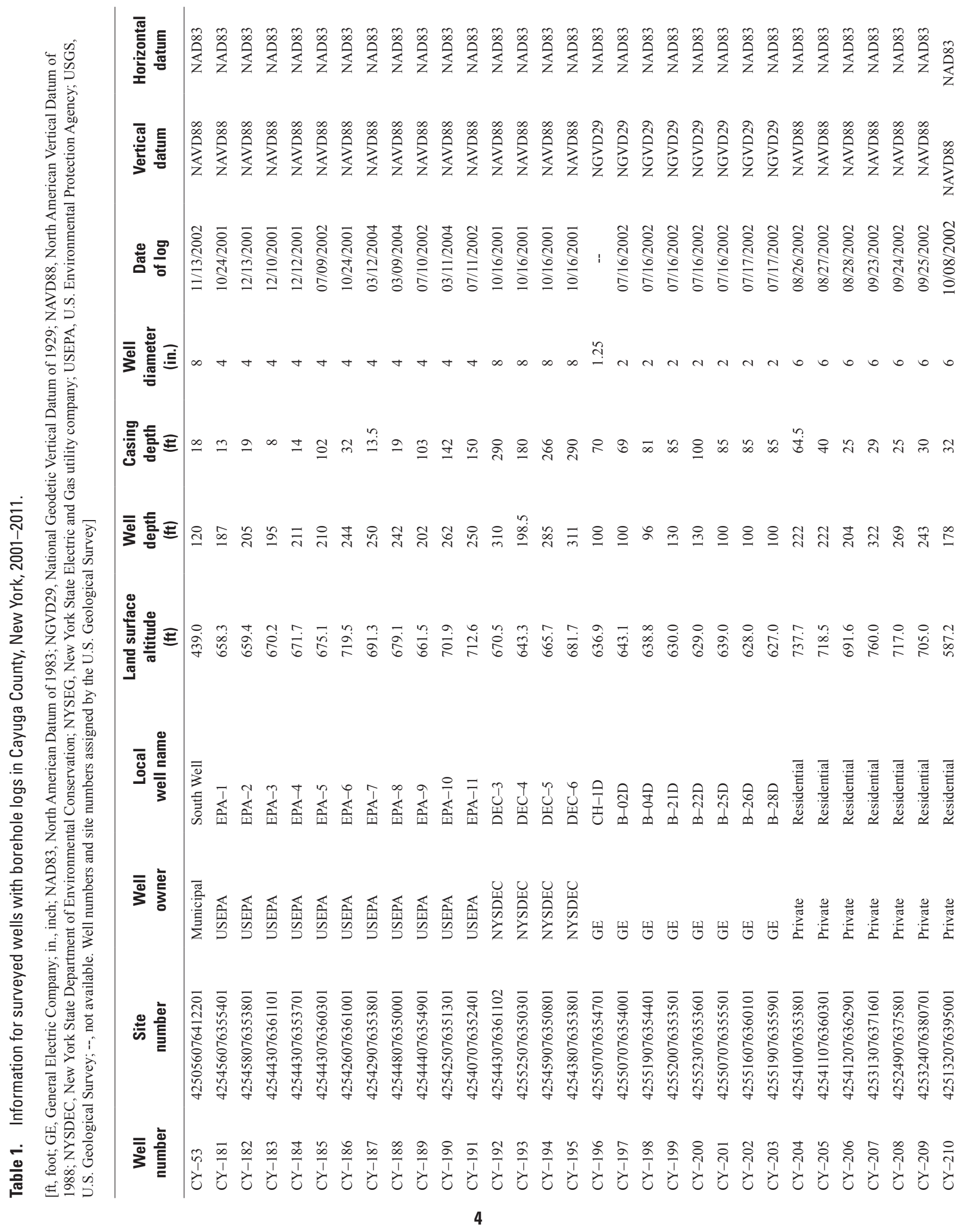




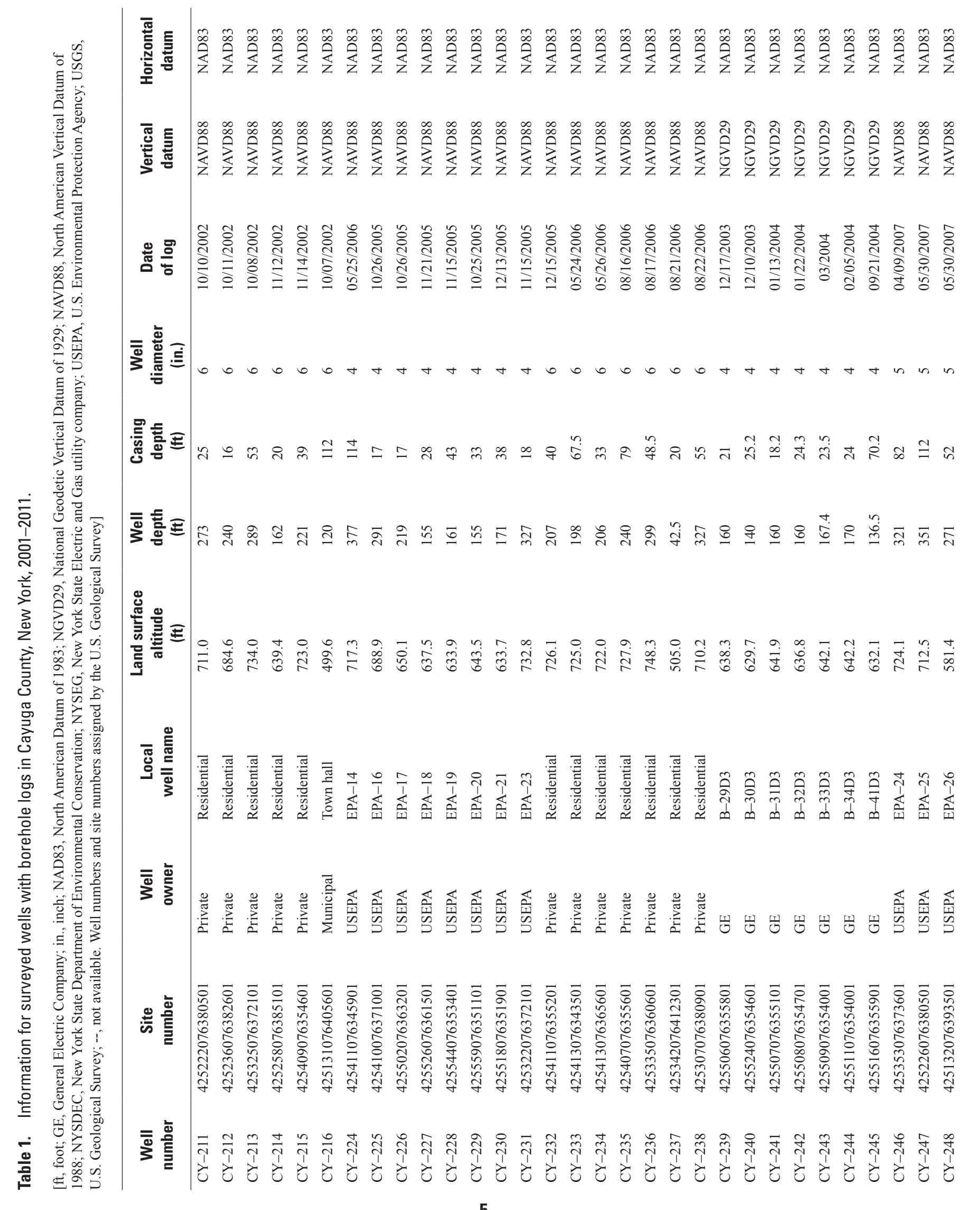




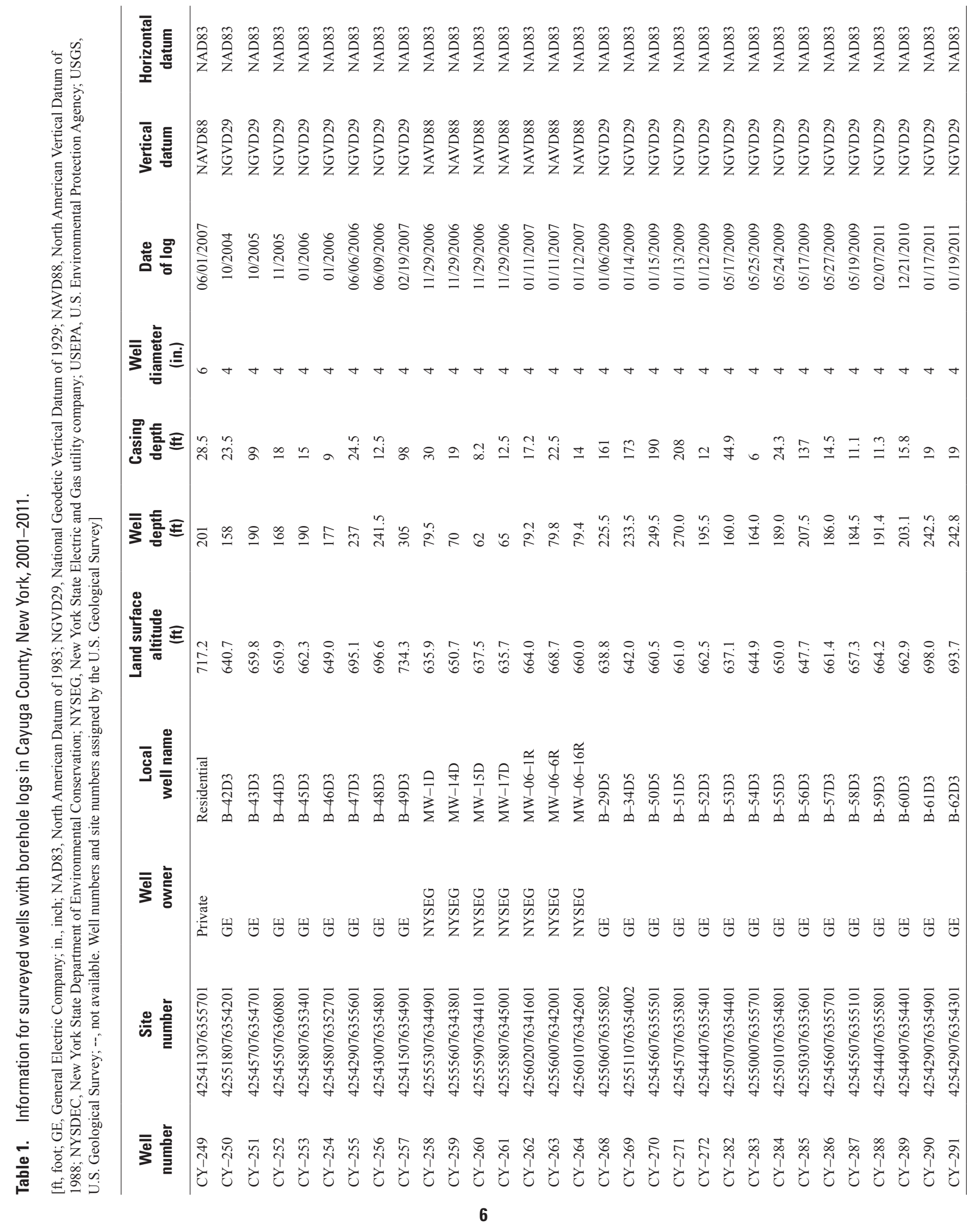


Table 2. Borehole information collected for wells surveyed in Cayuga County, New York, 2001-2011.

[GE, General Electric Company; REAC, Response Engineering and Analytical Contractor; USGS, U.S. Geological Survey. Well number assigned by the USGS. USGS standard log suite: Gamma, caliper, optical-and(or) acoustic-televiewer, deviation, fluid-resistivity, and temperature logs; caliper, televiewer, and deviation were not collected from wells CY 259 and 260; REAC standard log suite: Gamma, fluid-resistivity, and temperature logs; GE standard log suite: Gamma, single-point resistance, caliper, optical-and/or acousticteleviewer, deviation, fluid-resistivity, and temperature logs.]

\begin{tabular}{|c|c|c|c|c|c|c|c|}
\hline $\begin{array}{c}\text { Well } \\
\text { no. }\end{array}$ & $\begin{array}{c}\text { Local } \\
\text { well name }\end{array}$ & $\begin{array}{c}\text { Log } \\
\text { source }\end{array}$ & $\begin{array}{l}\text { Standard } \\
\text { log suite }\end{array}$ & $\begin{array}{l}\text { Ambient } \\
\text { flow log }\end{array}$ & $\begin{array}{l}\text { Pumped } \\
\text { flow log }\end{array}$ & $\begin{array}{c}\text { Borehole } \\
\text { video }\end{array}$ & $\begin{array}{c}\text { Core } \\
\text { samples }\end{array}$ \\
\hline CY-53 & South Well & USGS & $X$ & $\mathrm{X}$ & $X$ & $\mathrm{X}$ & \\
\hline CY-181 & EPA-1 & USGS & $\mathrm{X}$ & $\mathrm{X}$ & $\mathrm{X}$ & $\mathrm{X}$ & $\mathrm{X}$ \\
\hline CY-182 & EPA-2 & USGS & X & $X$ & & & \\
\hline CY-183 & EPA-3 & USGS & $\mathrm{X}$ & $\mathrm{X}$ & & & \\
\hline CY-184 & EPA-4 & USGS & $\mathrm{X}$ & $X$ & & & \\
\hline CY-185 & EPA-5 & USGS & $\mathrm{X}$ & $\mathrm{X}$ & $\mathrm{X}$ & & \\
\hline CY-186 & EPA-6 & USGS & $X$ & $X$ & & $X$ & $X$ \\
\hline CY-187 & EPA-7 & USGS & $\mathrm{X}$ & $\mathrm{X}$ & $\mathrm{X}$ & & \\
\hline CY-188 & EPA-8 & USGS & $X$ & $\mathrm{X}$ & & & \\
\hline CY-189 & EPA-9 & USGS & $\mathrm{X}$ & $\mathrm{X}$ & & & \\
\hline CY-190 & EPA-10 & USGS & $X$ & $\mathrm{X}$ & & & \\
\hline CY-191 & EPA-11 & USGS & $\mathrm{X}$ & $\mathrm{X}$ & & & \\
\hline CY-192 & DEC-3 & REAC & $\mathrm{X}$ & & & & \\
\hline CY-193 & DEC-4 & REAC & $\mathrm{X}$ & & & & \\
\hline CY-194 & DEC-5 & REAC & $\mathrm{X}$ & & & & \\
\hline CY-195 & DEC-6 & REAC & $\mathrm{X}$ & & & & \\
\hline CY-196 & CH-1D & GE & & & & & $\mathrm{X}$ \\
\hline CY-197 & B-02D & USGS & $\mathrm{X}$ & $X$ & & & \\
\hline CY-198 & B-04D & USGS & $\mathrm{X}$ & $\mathrm{X}$ & & & \\
\hline CY-199 & B-21D & USGS & $\mathrm{X}$ & $\mathrm{X}$ & & & \\
\hline CY-200 & B-22D & USGS & $X$ & $\mathrm{X}$ & & & \\
\hline CY-201 & $B-25 D$ & USGS & $\mathrm{X}$ & $\mathrm{X}$ & & & \\
\hline CY-202 & $B-26 D$ & USGS & $\mathrm{X}$ & $\mathrm{X}$ & & & \\
\hline CY-203 & B-28D & USGS & $\mathrm{X}$ & $\mathrm{X}$ & & & \\
\hline CY-204 & Residential & USGS & $\mathrm{X}$ & $\mathrm{X}$ & & & \\
\hline CY-205 & Residential & USGS & $\mathrm{X}$ & $\mathrm{X}$ & & & \\
\hline CY-206 & Residential & USGS & $X$ & $X$ & & & \\
\hline CY-207 & Residential & USGS & $\mathrm{X}$ & $\mathrm{X}$ & & & \\
\hline CY-208 & Residential & USGS & $X$ & $\mathrm{X}$ & & & \\
\hline CY-209 & Residential & USGS & $X$ & $\mathrm{X}$ & & & \\
\hline CY-210 & Residential & USGS & $X$ & $\mathrm{X}$ & & & \\
\hline CY-211 & Residential & USGS & $\mathrm{X}$ & $\mathrm{X}$ & & & \\
\hline $\mathrm{CY}-212$ & Residential & USGS & $\mathrm{X}$ & $\mathrm{X}$ & & & \\
\hline CY-213 & Residential & USGS & $X$ & $X$ & & & \\
\hline CY-214 & Residential & USGS & $\mathrm{X}$ & $\mathrm{X}$ & & & \\
\hline CY-215 & Residential & USGS & $X$ & $X$ & & & \\
\hline CY-216 & Town hall & USGS & $\mathrm{X}$ & $\mathrm{X}$ & $X$ & & \\
\hline $\mathrm{CY}-224$ & EPA-14 & USGS & $X$ & $X$ & $\mathrm{X}$ & & $X$ \\
\hline CY-225 & EPA-16 & USGS & $\mathrm{X}$ & $\mathrm{X}$ & $\mathrm{X}$ & $\mathrm{X}$ & $\mathrm{X}$ \\
\hline
\end{tabular}


Table 2. Borehole information collected for wells surveyed in Cayuga County, New York, 2001-2011.

[USGS, U.S. Geological Survey; REAC, Response Engineering and Analytical Contractor; GE, General Electric Company. Well number assigned by U.S. Geological Survey. USGS standard log suite: Gamma, caliper, optical-and/or acoustic-televiewer, deviation, fluidresistivity, and temperature logs; caliper, televiewer, and deviation were not collected from wells CY 259 and 260; REAC standard log suite: Gamma, fluid-resistivity, and temperature logs; GE standard log suite: Gamma, single-point resistance, caliper, optical-and/or acoustic-televiewer, deviation, fluid-resistivity, and temperature logs.]

\begin{tabular}{|c|c|c|c|c|c|c|c|}
\hline $\begin{array}{c}\text { Well } \\
\text { no. }\end{array}$ & $\begin{array}{c}\text { Local } \\
\text { well name }\end{array}$ & $\begin{array}{l}\text { Log } \\
\text { source }\end{array}$ & $\begin{array}{l}\text { Standard } \\
\text { log suite }\end{array}$ & $\begin{array}{l}\text { Ambient } \\
\text { flow log }\end{array}$ & $\begin{array}{l}\text { Pumped } \\
\text { flow log }\end{array}$ & $\begin{array}{c}\text { Borehole } \\
\text { video }\end{array}$ & $\begin{array}{c}\text { Core } \\
\text { samples }\end{array}$ \\
\hline CY-226 & EPA-17 & USGS & $\mathrm{X}$ & $\mathrm{X}$ & $\mathrm{X}$ & & \\
\hline CY-227 & EPA-18 & USGS & $X$ & X & $\mathrm{X}$ & & X \\
\hline CY-228 & EPA-19 & USGS & $\mathrm{X}$ & $\mathrm{X}$ & $\mathrm{X}$ & & \\
\hline CY-229 & EPA-20 & USGS & $\mathrm{X}$ & $\mathrm{X}$ & $\mathrm{X}$ & & \\
\hline CY-230 & EPA-21 & USGS & $\mathrm{X}$ & $\mathrm{X}$ & & & $X$ \\
\hline CY-231 & EPA-23 & USGS & $X$ & $\mathrm{X}$ & & & \\
\hline CY-232 & Residential & USGS & $\mathrm{X}$ & $\mathrm{X}$ & & & \\
\hline CY-233 & Residential & USGS & $\mathrm{X}$ & $\mathrm{X}$ & & & \\
\hline CY-234 & Residential & USGS & $\mathrm{X}$ & $\mathrm{X}$ & & & \\
\hline CY-235 & Residential & USGS & $\mathrm{X}$ & $\mathrm{X}$ & & & \\
\hline CY-236 & Residential & USGS & $\mathrm{X}$ & $\mathrm{X}$ & & & \\
\hline CY-237 & Residential & USGS & $\mathrm{X}$ & $\mathrm{X}$ & & & \\
\hline CY-238 & Residential & USGS & $\mathrm{X}$ & $X$ & & $\mathrm{X}$ & $\mathrm{X}$ \\
\hline CY-239 & B-29D3 & GE & $\mathrm{X}$ & $\mathrm{X}$ & $\mathrm{X}$ & $\mathrm{X}$ & $\mathrm{X}$ \\
\hline CY-240 & B-30D3 & GE & $X$ & $\mathrm{X}$ & $\mathrm{X}$ & $\mathrm{X}$ & $\mathrm{X}$ \\
\hline CY-241 & B-31D3 & GE & $\mathrm{X}$ & $\mathrm{X}$ & $\mathrm{X}$ & $\mathrm{X}$ & $\mathrm{X}$ \\
\hline CY-242 & B-32D3 & GE & $\mathrm{X}$ & $\mathrm{X}$ & $\mathrm{X}$ & $\mathrm{X}$ & $\mathrm{X}$ \\
\hline CY-243 & B-33D3 & GE & $\mathrm{X}$ & $\mathrm{X}$ & $\mathrm{X}$ & $\mathrm{X}$ & $\mathrm{X}$ \\
\hline CY-244 & B-34D3 & GE & $\mathrm{X}$ & $\mathrm{X}$ & $\mathrm{X}$ & $\mathrm{X}$ & $\mathrm{X}$ \\
\hline CY-245 & B-41D3 & GE & $\mathrm{X}$ & $\mathrm{X}$ & $\mathrm{X}$ & $\mathrm{X}$ & $\mathrm{X}$ \\
\hline CY-246 & EPA-24 & USGS & $\mathrm{X}$ & $\mathrm{X}$ & $\mathrm{X}$ & & $\mathrm{X}$ \\
\hline CY-247 & EPA-25 & USGS & $\mathrm{X}$ & $\mathrm{X}$ & $\mathrm{X}$ & & $\mathrm{X}$ \\
\hline CY-248 & EPA-26 & USGS & $\mathrm{X}$ & $\mathrm{X}$ & $\mathrm{X}$ & & $\mathrm{X}$ \\
\hline CY-249 & Residential & USGS & $\mathrm{X}$ & $\mathrm{X}$ & $\mathrm{X}$ & & \\
\hline CY-250 & B-42D3 & GE & $\mathrm{X}$ & $\mathrm{X}$ & $\mathrm{X}$ & $\mathrm{X}$ & $\mathrm{X}$ \\
\hline CY-251 & B-43D3 & GE & $\mathrm{X}$ & $\mathrm{X}$ & $\mathrm{X}$ & $\mathrm{X}$ & $\mathrm{X}$ \\
\hline CY-252 & B-44D3 & GE & $\mathrm{X}$ & $\mathrm{X}$ & $\mathrm{X}$ & $\mathrm{X}$ & $\mathrm{X}$ \\
\hline CY-253 & B-45D3 & GE & $\mathrm{X}$ & $\mathrm{X}$ & $\mathrm{X}$ & $\mathrm{X}$ & $\mathrm{X}$ \\
\hline CY-254 & B-46D3 & GE & $\mathrm{X}$ & $\mathrm{X}$ & $\mathrm{X}$ & $\mathrm{X}$ & $\mathrm{X}$ \\
\hline CY-255 & B-47D3 & GE & $\mathrm{X}$ & $\mathrm{X}$ & $\mathrm{X}$ & $\mathrm{X}$ & $\mathrm{X}$ \\
\hline CY-256 & B-48D3 & GE & $\mathrm{X}$ & $\mathrm{X}$ & $\mathrm{X}$ & $\mathrm{X}$ & $\mathrm{X}$ \\
\hline CY-257 & B-49D3 & GE & $\mathrm{X}$ & $\mathrm{X}$ & $\mathrm{X}$ & & $\mathrm{X}$ \\
\hline CY-258 & MW-1D & USGS & $\mathrm{X}$ & $\mathrm{X}$ & $\mathrm{X}$ & & \\
\hline CY-259 & MW-14D & USGS & $\mathrm{X}$ & $\mathrm{X}$ & $\mathrm{X}$ & & \\
\hline CY-260 & MW-15D & USGS & $\mathrm{X}$ & $\mathrm{X}$ & $\mathrm{X}$ & & \\
\hline CY-261 & MW-17D & USGS & $\mathrm{X}$ & $\mathrm{X}$ & & & \\
\hline CY-262 & MW-06-1R & USGS & $\mathrm{X}$ & $\mathrm{X}$ & $\mathrm{X}$ & & \\
\hline CY-263 & MW-06-6R & USGS & $\mathrm{X}$ & $\mathrm{X}$ & $\mathrm{X}$ & & \\
\hline CY-264 & MW-06-16R & USGS & $\mathrm{X}$ & $X$ & $\mathrm{X}$ & & \\
\hline
\end{tabular}


Table 2. Borehole information collected for wells surveyed in Cayuga County, New York, 2001-2011.

[USGS, U.S. Geological Survey; REAC, Response Engineering and Analytical Contractor; GE, General Electric Company. Well number assigned by U.S. Geological Survey. USGS standard log suite: Gamma, caliper, optical-and/or acoustic-televiewer, deviation, fluidresistivity, and temperature logs; caliper, televiewer, and deviation were not collected from wells CY 259 and 260; REAC standard log suite: Gamma, fluid-resistivity, and temperature logs; GE standard log suite: Gamma, single-point resistance, caliper, optical-and/or acoustic-televiewer, deviation, fluid-resistivity, and temperature logs.]

\begin{tabular}{|c|c|c|c|c|c|c|c|}
\hline $\begin{array}{l}\text { Well } \\
\text { no. }\end{array}$ & $\begin{array}{l}\text { Local } \\
\text { well name }\end{array}$ & $\begin{array}{l}\text { Log } \\
\text { source }\end{array}$ & $\begin{array}{l}\text { Standard } \\
\text { log suite }\end{array}$ & $\begin{array}{l}\text { Ambient } \\
\text { flow log }\end{array}$ & $\begin{array}{l}\text { Pumped } \\
\text { flow log }\end{array}$ & $\begin{array}{c}\text { Borehole } \\
\text { video }\end{array}$ & $\begin{array}{c}\text { Core } \\
\text { samples }\end{array}$ \\
\hline CY-268 & B-29D5 & GE & $\mathrm{X}$ & $\mathrm{X}$ & $\mathrm{X}$ & $\mathrm{X}$ & $X$ \\
\hline CY-269 & B-34D5 & GE & $\mathrm{X}$ & $\mathrm{X}$ & $\mathrm{X}$ & $\mathrm{X}$ & $\mathrm{X}$ \\
\hline CY-270 & B-50D5 & GE & $\mathrm{X}$ & $\mathrm{X}$ & $\mathrm{X}$ & $\mathrm{X}$ & $\mathrm{X}$ \\
\hline CY-271 & B-51D5 & GE & $\mathrm{X}$ & $\mathrm{X}$ & & $\mathrm{X}$ & $\mathrm{X}$ \\
\hline CY-272 & B-52D3 & GE & $\mathrm{X}$ & $\mathrm{X}$ & $\mathrm{X}$ & $\mathrm{X}$ & $\mathrm{X}$ \\
\hline CY-282 & B-53D3 & GE & $\mathrm{X}$ & $\mathrm{X}$ & $\mathrm{X}$ & $\mathrm{X}$ & $\mathrm{X}$ \\
\hline CY-283 & B-54D3 & GE & $\mathrm{X}$ & $\mathrm{X}$ & $\mathrm{X}$ & $\mathrm{X}$ & $\mathrm{X}$ \\
\hline CY-284 & $\mathrm{B}-55 \mathrm{D} 3$ & GE & $\mathrm{X}$ & $\mathrm{X}$ & $\mathrm{X}$ & $\mathrm{X}$ & $\mathrm{X}$ \\
\hline CY-285 & B-56D3 & GE & $\mathrm{X}$ & $\mathrm{X}$ & & & $\mathrm{X}$ \\
\hline CY-286 & B-57D3 & GE & $\mathrm{X}$ & $\mathrm{X}$ & $\mathrm{X}$ & $\mathrm{X}$ & $\mathrm{X}$ \\
\hline CY-287 & B-58D3 & GE & $\mathrm{X}$ & $\mathrm{X}$ & $\mathrm{X}$ & $\mathrm{X}$ & $\mathrm{X}$ \\
\hline CY-288 & B-59D3 & GE & $\mathrm{X}$ & $\mathrm{X}$ & $\mathrm{X}$ & $\mathrm{X}$ & $\mathrm{X}$ \\
\hline CY-289 & B-60D3 & GE & $\mathrm{X}$ & $\mathrm{X}$ & $\mathrm{X}$ & $\mathrm{X}$ & $\mathrm{X}$ \\
\hline CY-290 & B-61D3 & GE & X & X & X & X & X \\
\hline CY-291 & B-62D3 & GE & X & X & X & X & X \\
\hline
\end{tabular}

Single-point resistance logs record the electrical resistance from points within the borehole to an electrical ground at land surface. Resistance generally increases with increasing grain size and decreases with increasing borehole diameter, fracture density, and the concentration of dissolved solids in the water. Single-point resistance logs are useful in the determination of lithology, water quality, and location of fracture zones and solution features.

Mechanical- and acoustic-caliper logs record the diameter of the wellbore. Changes in wellbore diameter are related to drilling and construction procedures and competency of lithologic units, fractures, and solution features. Mechanical-caliper logs were collected with a spring-loaded, three-arm averaging tool; acoustic-caliper logs were calculated from acoustic travel times collected with the acoustic-televiewer tool. Caliper logs were used in the delineation of fractures, solution features, and lithology, and to confirm or determine well and casing depths and diameters.

Video-camera logs record an optical "fisheye" view of the wellbore and can be collected above water level and in areas below the surface of the water where the water is clear. Video-camera logs were used to directly view well and casing conditions, bedding and lithologic contacts, fractures, solution features, and cascading water from flow zones above the water level. The video logs are on file on DVD and are available for viewing at the USGS office in Troy, N.Y. (http://ny.usgs.gov/).

OTV and ATV logs record 360-degree, magnetically oriented images of the wellbore wall (Williams and Johnson, 2000, 2004). The OTV and ATV logs were used to characterize the distribution and orientation of planar fracture and bedding features intersected by the test wells. Fracture delineations from OTV and ATV logs of near-vertical wells may oversample low-angle fractures and undersample high-angle fractures.

Borehole-deviation logs show the tilt angle (in degrees from the vertical datum) and the azimuth of the tilt (in degrees from magnetic north) of the borehole.

Fluid-resistivity and temperature logs record the electrical resistivity and temperature of water in the wells. Fluid resistivity is directly related to the concentration of dissolved solids in the water. Slope changes in fluid-resistivity and temperature logs collected under ambient conditions may indicate zones of inflow to or outflow from the well. Collection of fluid-resistivity and temperature logs under pumped conditions provided an additional level of enhancement in flow-zone delineation in selected wells.

Flow logs record the direction and rate of vertical flow in the well. Vertical flow occurs under ambient conditions in wells that penetrate two or more flow zones under differing hydraulic head. Borehole flow under ambient conditions and, in selected wells, pumped or injection conditions was measured using heat-pulse, electromagnetic, and spinner flowmeters. Heat-pulse 
flowmeters, which are used in a stationary measurement mode, determines vertical flow based on the travel time of a thermal pulse between a set of upper and lower thermisters (Hess, 1982; Herman, 2006). The heat-pulse flowmeter used by the USGS, which was configured with a flexible rubber diverter fitted to the borehole diameter, has a measurement range of 0.005 to 1.0 gallon per minute (gal/min). The heat-pulse flowmeter used by the private contractor, which was not configured with a diverter, has a measurement range of 0.2 to $6.5 \mathrm{gal} / \mathrm{min}$ in the 4-in. diameter monitor wells in which it was deployed. Electromagnetic flowmeters (Young and Pearson, 1995), which are used in stationary and trolling modes, measure fluid velocity based on Faraday's Law; in application, the flow of the electrically-conductive fluid (water) through a magnetic field induced by the flowmeter generates a measurable voltage gradient that is proportional to the fluid's velocity. The electromagnetic flowmeter used by the USGS, which was configured with a flexible rubber diverter fitted to the borehole diameter, has a measurement range of 0.05 to $10 \mathrm{gal} / \mathrm{min}$. Spinner flowmeters measure vertical flow by recording the rotation rate of a multiple-bladed impeller mounted with adjustable needle bearings on a freely rotating shaft (Keys, 1990). The spinner flowmeter used by the private contractor in a trolling mode has a low-threshold measurement of $2.1 \mathrm{gal} / \mathrm{min}$ in the 4 -in. diameter monitor wells in which it was deployed.

\section{Stratigraphic Logs}

The stratigraphic logs delineate the geologic formations and members penetrated by the wells. The stratigraphy of central New York has been described by Harris (1905), Luther (1910), Oliver (1954), Rickard (1962, 1975, 1989), Demicco and others (1992), Brett and Ver Straeten (1994), and Brett and others (2000). The stratigraphic units penetrated by 41 of the 93 wells were identified by characterization of available core samples and their correlation to gamma logs. The stratigraphic units penetrated by wells without rock core samples were identified by characteristic signatures in the gamma logs; supporting information from the OTV and ATV logs was used where available.

The wells penetrate limestones, dolostones, shales, sandstones, and evaporites of Silurian to Devonian age. The identified stratigraphic units of Silurian age, in ascending order, are the Camillus Shale; the Fiddlers Green, Forge Hollow, and Oxbow Members of the Bertie Formation; the Cobleskill Limestone; and the lower part of the Chrysler Member of the Rondout Formation. The contact between the Camillus Shale and the Fiddlers Green dolostone (basal unit of the Bertie Formation) was identified in wells from characteristic core-sample lithologies and gamma signatures. The upper part of the Forge Hollow Member of the Bertie Formation (referred to as the D3 flow zone) is gypsum and argillaceous gypsiferous dolostone that has significant solution features that are seen in many borehole logs as open voids, typically within the top $15 \mathrm{ft}$ of the Forge Hollow Member contact with the overlying Oxbow Member. The presence of the Akron Dolomite, which may interfinger locally with the Cobleskill Limestone as an equivalent dolomitized facies (Brett and others, 2000) and which may be penetrated by some wells, could not be confirmed through the geophysical log analysis.

The identified stratigraphic units of Devonian age, in ascending order, are the upper part of the Chrysler Member of the Rondout Formation; the Olney Member of the Manlius Formation; the Edgecliff, Nedrow, Moorehouse, and Seneca Members of the Onondaga Limestone; the Union Springs, Cherry Valley Limestone, and Oatka Creek Members of the Marcellus Shale; and the Mottville and Delphi Station Members of the Skaneateles Formation. The Mottville shale and sandstone and the Delphi Station shale, which were penetrated in only a few wells, were tentatively identified from characteristic thicknesses and gamma signatures. The Mottville Member is partly exposed in a road cut along State Route 326, about 1 mile (mi) south of Half Acre, N.Y. (fig. 1, outcrop site A).

The Oriskany Sandstone and the Springvale Sandstone of the Tri-States Group in central New York are discontinuously present between the Manlius Formation and Onondaga Limestone (Brett and others, 2000). The Oriskany and Springvale were not present in rock cores from wells nor in exposures at the Oakwood quarry (fig. 1, outcrop site B) or along State Route 5 and U.S. Route 20 near the Finger Lakes Mall (fig. 1, outcrop site C). However, a 3-ft-thick section of the Oriskany Sandstone is present at the Yawgers Woods outcrop (fig. 1, outcrop site D) described by Luther (1910). At the Schooley quarry (fig. 1, outcrop site E), no Oriskany Sandstone is present but a thin discontinuous bed of the Springvale Sandstone with its characteristic phosphate nodules is present. The Oriskany Sandstone and Springvale Sandstone were not identified through the geophysical log analysis, although relatively thin sections of these units may be penetrated by some of the wells. Clasts of reworked phosphate nodules from the Springvale Sandstone are present at the base of the Edgecliff Member of the Onondaga Limestone in many of the rock cores and in exposures at the Oakwood and Schooley quarries and along State Route 5 and U.S. Route 20 near the Finger Lakes Mall. The phosphate nodules produce a characteristic gamma peak that facilitates the identification of the contact between the Onondaga and Manlius Formations, which is a major erosional unconformity. Another significant gamma peak is produced by the Tioga Bentonite, which is a thin volcanic ash deposit at the contact of the Seneca and Moorehouse Members of the Onondaga Limestone (Ver Straeten, 2004).

Repeated stratigraphic sections were identified within the Manlius Formation in well CY-205, the Manlius and Onondaga Formations in well CY-212, and the Onondaga Formation and the Marcellus Shale in wells CY-215 and CY-225. The repeated 
sections are likely owing to localized thrust faults similar to that described by Conkin and Conkin (1984) and Duskin (1969) west and east of the study area.

\section{Flow-Zone Logs}

The flow-zone logs define the distribution and relative hydraulic head of flow zones penetrated by selected wells. The distribution and character of flow zones were determined by the integrated analysis of the caliper, OTV and ATV, fluid-resistivity, temperature, and flow logs. At least one feature within each zone was designated as an hydraulically active fracture or solution feature that contributes to the measured ambient or pumped flows (Paillet, 1998; 2000). Most flow zones were associated with bedding-related permeability including bedding fractures and solution features.

The ambient water levels measured in the open-hole multi-zone wells are composite hydraulic heads that reflect the transmissivity-weighted average of the heads of the penetrated flow zones (Bennett and others, 1982, Williams and Lane, 1998). Heads in inflow zones are higher than the composite water level, and outflow zones are lower than the composite water level.

\section{Selected References}

American Society for Testing and Materials, 2010, Standard guide for planning and conducting borehole geophysical loggingASTM D5753-05(2010), in Soil and rock; American Society for Testing and Materials Annual Book of ASTM Standards, v. $04.08,8 \mathrm{p}$.

Anderson, J.A., Williams, J.H., Eckhardt, D.A.V., and Miller, T.S., 2004, Geophysical, stratigraphic, and flow-zone logs of selected test, monitor, and water-supply wells in Cayuga County, New York: U.S. Geological Survey Open-File Report 2003-468, 10 p. plus appendix, accessed April 4, 2011, at http://ny.water.usgs.gov/pubs/of/of03468/.

Bennett, G.D., Kontis, A.L., and Larson, S.P., 1982, Representation of multiaquifer-well effects in three-dimensional groundwater flow simulation: Ground Water, v. 20, no. 3, p. 334-341.

Brett, C.E., and Ver Straeten, C.A., 1994, Stratigraphy and facies relationships of the Eifelian Onondaga Limestone (Middle Devonian) in western and central New York state, in New York State Geological Association, 66th annual meeting, Rochester, N.Y., Oct. 7-9, 1994, Field trip guidebook: New York State Geological Association Guidebook 66, p. 221-269. [Edited by C.E. Brett and James Scatteday.]

Brett, C.E., Ver Straeten, C.A., and Baird, G.C., 2000, Anatomy of a composite sequence boundary-The Silurian-Devonian contact in western New York state, in New York State Geological Association, 72d annual meeting, Geneva, N.Y., Sept. 29Oct. 1, 2000, Field trip guidebook: New York State Geological Association Guidebook 72, p. 39-72. [Edited by D.L. Woodrow and D.B. McKinney.]

Conkin, J.E., and Conkin, B.M., 1984, Devonian metabentonites in the eastern United States and southern Ontario; Their identities, stratigraphic positions, and correlation, pt. 1 of Paleozoic metabentonites of North America: University of Louisville Studies in Paleontology and Stratigraphy, no.16, p. 92-93.

Demicco, R.V., Lowenstien, T.K., and Browne, K.M., 1992, Comparative sedimentology of the lower Manlius Formation near Hamilton, New York, in New York State Geological Association, 66th annual meeting, Hamilton, N.Y., Sept. 18-20, 1992, Field trip guidebook: New York State Geological Association Guidebook 64, p. 57-71. [Edited by R.H. April.]

Duskin, D.J., 1969, Economic geology of the gypsum deposits at Union Springs, New York: Ithaca, N.Y., Cornell University M.S. thesis, $134 \mathrm{p}$.

Harris, G.D., 1905, Guide to the geology of Union Springs: Cornell University Elementary Natural History Series, no. 3, 12 p.

Herman, G.C., 2006, Field tests using a heat-pulse flow meter to determine its accuracy for flow measurements in bedrock wells: New Jersey Geological Survey Technical Memorandum 06-1, 8 p.

Hess, A.E., 1982, A heat-pulse flowmeter for measuring low velocities in boreholes: U.S. Geological Survey Open-File Report 82-699, $44 \mathrm{p}$.

Kantrowitz, I.H., 1970, Ground-water resources in the eastern Oswego River basin, New York: New York State Water Resources Commission Basin Planning Report ORB-2, 47 p. 
Keys, W.S., 1990, Borehole geophysics applied to ground-water investigations: U.S. Geological Survey Techniques of WaterResources Investigations, book 2, chap. E2, p. 150.

Luther, D.D., 1910, Geology of the Auburn-Genoa quadrangles: New York State Museum Bulletin 137, 32 p.

Oliver, W.A., 1954, Stratigraphy of the Onondaga Limestone (Devonian) in central New York: Geological Society of America Bulletin, v. 65, no. 7, p. 621-652.

Paillet, F.L., 1998, Flow modeling and permeability estimation using borehole flow logs in heterogeneous fractured formations: Water Resources Research, v. 34, no. 5, p. 997-1010.

Paillet, F.L., 2000, A field technique for estimating aquifer parameters using flow data: Ground Water, v. 38, no. 4, p. $510-521$.

Rickard, L.V., 1962, Late Cayugan (Upper Silurian) and Helderbergian (Lower Devonian) stratigraphy in New York state: New York State Museum Science Service Bulletin 386, 157 p.

Rickard, L.V., 1975, Correlation of the Silurian and Devonian rocks in New York state: New York State Museum Map and Chart Series, no. 24, 4 plates, 16-p. text.

Rickard, L.V., 1989, Stratigraphy of the subsurface Lower and Middle Devonian of New York, Pennsylvania, Ohio, and Ontario: New York State Museum Map and Chart Series, no. 39, 40 plates, 59-p. text.

U.S. Environmental Protection Agency, 2002, NPL site narrative for Cayuga County ground water contamination site: U.S. Environmental Protection Agency, accessed October 28, 2011, at http://www.epa.gov/superfund/sites/nplsnl/n0204289.pdf.

Ver Straeten, C.A., 2004, K-bentonites, volcanic ash preservation, and implications for Early to Middle Devonian volcanism in the Acadian orogen, eastern North America: Geological Society of America Bulletin, v. 116, no. 3/4, p. 474-489.

Williams, J.H., 2008, Flow-log analysis for hydraulic characterization of selected test wells at the Indian Point Energy Center, Buchanan, New York: U.S. Geological Survey Open-File Report 2008-1123, 30 p., accessed April 4, 2011, at http://pubs.usgs.gov/of/2008/1123/.

Williams, J.H., and Johnson, C.D., 2000, Borehole-wall imaging with acoustic and optical televiewers for fractured-bedrock aquifer investigations, in International Symposium on Borehole Geophysics for Minerals, Geotechnical, and Groundwater Applications, 7th, Golden, Colo., October 24-26, 2000, Proceedings: Minerals and Geotechnical Logging Society, p. 43-53.

Williams, J.H., and Johnson, C.D., 2004, Acoustic and optical borehole-wall imaging for fractured-rock aquifer studies: Journal of Applied Geophysics, v. 55, issue 1-2, p. 151-159.

Williams, J.H., and Lane, J.W., 1998, Advances in borehole geophysics for groundwater investigations: U.S. Geological Survey Fact Sheet 2002-98, 4 p.

Young, S.C., and Pearson, H.S., 1995, The electromagnetic borehole flowmeter-Description and application: Ground Water Monitoring and Remediation Review, v. 15, no. 4, p. 138-147. 


\section{Appendix 1. Explanations For Abbreviations Used in Composites of Geophysical, Stratigraphic, and Flow-Zone Logs for Selected Wells, Cayuga County, New York, 2001-2011}

The logs are available for display and download in log Ascii standard (LAS), portable document format (PDF), and WellCad (WCL) formats from the USGS geophysical log archive at http://ny.water.usgs.gov/projects/geologs. The WellCad Reader program, which may be obtained free of charge through http://www.alt.lu/downloads.htm, allows the logs to be displayed, tabulated, and printed at user-specified vertical scales.

\section{Explanation}

Depth-Depth, in feet below land surface at specified vertical scale

Form-Stratigraphic formation

Mmb-Stratigraphic member

Gamma-Natural gamma radiation, in counts per second

Mech Cal-Mechanical three-arm caliper, borehole diameter in inches

Acou Cal-Acoustic caliper from travel times collected with acoustic televiewer, borehole diameter in inches

ATV-Acoustic-televiewer image; 360-degree acoustic image of borehole wall; MN indicates log oriented to magnetic north; HS indicates log oriented to high side of borehole wall

OTV_-Optical-televiewer image; 360-degree optical image of borehole wall; MN indicates log oriented to magnetic north; HS indicates log oriented to high side of borehole wall

SPR_-Single-point resistance, in ohms

FI Res-Fluid resistivity, in ohms per meter; blue line indicates log collected under ambient conditions; red line indicates log collected under pumped conditions (pmp); green line indicates log collected under injection conditions (inj)

Temp-Temperature, in degrees Celsius; blue line indicates log collected under ambient conditions; red line indicates log collected under pumped conditions (pmp); green line indicates log collected under injection conditions (inj)

Flow-Borehole flow measured by stationary flowmeter, in gallons per minute; ND indicates log collected without flow diverter; blue disk indicates log collected under ambient conditions; red square indicates log collected under pumped conditions (pmp); green triangle indicates log collected under injection conditions (inj)

Troll-Borehole flow measured by trolling flowmeter; scale adjusted to matched stationary flowmeter measurements; blue line indicates log collected under ambient conditions; red line indicates log collected under pumped conditions (pmp)

Flow zone-Flow zone; blue line indicates ambient composite hydraulic head; yellow line indicates inflow zone with head higher than composite head; red line indicates outflow zone with head lower than composite head; black line designates base of casing

Azi MN-Borehole deviation azimuth from magnetic north, in degrees.

Tilt-Borehole deviation angle from vertical, in degrees 

Prepared by the Pembroke Publishing Service Center

For additional information write to:

New York Water Science Center

U.S. Geological Survey

30 Brown Rd.

Ithaca, NY 14850

Information requests:

(518) 285-5602

or visit our Web site at: http://ny.water.usgs.gov 
㺃 